\title{
Mentoring Matters in Workplace: The Impact of Formal Mentoring Program on EFL Instructors' Performance at ELI, King Abdulaziz University, Saudi Arabia
}

\author{
Dr. Aishah Khojah $^{1} \&$ Fariha Asif ${ }^{2}$ \\ ${ }^{1}$ Assistant Professor, Head of Quality \& Development Unit, English Language Institute, King Abdulaziz \\ University, Jeddah, Kingdom of Saudi Arabia \\ ${ }^{2}$ English Language Lecturer, Coordinator-Mentoring Program, English Language Institute, King Abdulaziz \\ University, Jeddah, Kingdom of Saudi Arabia \\ Correspondence: Fariha Asif, English Language Institute, King Abdulaziz University, Jeddah, Kingdom of Saudi \\ Arabia
}

Received: March 4, 2020

Accepted: March 27, 2020

Online Published: March 28, 2020

doi: 10.5539/elt.v13n4p140

URL: https://doi.org/10.5539/elt.v13n4p140

\begin{abstract}
An unprecedented acceleration in globalization, cross-culture integration and intensified innovation are a few elements that have triggered the need for availability of mentoring as the professional identity of any institution of higher learning. It has got the status of a foundation stone of mutual accomplishments between universities in the provision of teacher development. Therefore, this research study was carried out to evaluate the experiences of faculty members who participated in a formal mentoring program organized by the English Language Institute (ELI) at King Abdulaziz University (KAU) from 2017 to 2019. In this mixed-method study, a questionnaire and semi-structured interviews were used to gather data in order to respond to questions connected to the effectiveness of the mentoring program for mentors and mentees. The study particularly sought to discover the character of the work issues discussed and the worth judged by participants as emerging from their contribution to a programmed mentoring correlation. Data analysis transpired that mentoring promoted all of those who participated in the program. The study concluded that mentoring could assist in constructing capability in two ways: featured and standardized mentoring of trainee teachers through overt mentoring practices, and demonstrating and deconstructing teaching methods and practices for mentors' pedagogical progression. This study emphasizes the worth and value of the formal mentoring program as a valued and fitting professional development approach.
\end{abstract}

Keywords: formal mentoring program, EFL instructors, professional development, mentors, mentees

\section{Introduction}

It is but a truth that the current century has witnessed revolutionary changes in every walk of life and teaching is, of course, no exception. The way the elements of education, content, mode of delivery, teaching tools, artifacts and means of assessment are undergoing transition, the need for a source of practical guidance has become more vital than ever. Mentoring and its consistent presence in any school of teaching and learning is becoming inevitable and unavoidable element. A thorough view of the body of literature on mentoring and its implcations may reaveal that a subtle poise of mentoring someone is not moulding and developing them in your own identity or icon, but permitting them to develop themselves. It is a kind of voluntary transference of one's knowledge skill and professional expertise to somone who is comparyively newer in the profession. It is both inspirational and machinal at the same time. This study will reflect on the conclusive nature of the venture of mentoring.

Professional training provides many different developmental opportunities for faculty members' personal growth. It builds skills, encourages reflection and helps increase employee satisfaction. The goal is to keep the employee up-to-date on current trends as well as help them develop new skills for advancement in the field. Professional development covers all kinds of assisted learning opportunities, covering from college/university degrees to formal coursework, conferences and also informal learning opportunities positioned in practice (The World Federation of Nuclear Medicine and Biology). There are a variety of approaches to professional development; mentoring happens to be one type of professional development approach. In this connection, the ELI Quality and Development Unit at Women Main Campus (WMC) provides professional development training services to its 
members with the prime aim of equipping them with the necessary teaching skills and guiding them overcome the difficulties they might encounter in the classroom. More specifically, the new mentoring program at the ELI targets instructors with little experience and/or who have not been previously trained. Moreover, it provides guidance and support to ELI faculty members who need assistance to develop workable solutions to classroom problems. The purpose of the program is to maximize faculty members' professional growth known technically as a Formal Mentoring Program (FMP), further description of this program is given in section 1.2.

To the best of the researchers' knowledge, there is not a single university in Saudi Arabia has started, established and implemented such a unique, valuable and supportive mentoring program for their faculty members at large with the only exception of the "Center for Teaching \& Learning Development" being run under the supervision of King Abdulaziz University. However, mentoring services at this center are limited to Saudi faculty who are newly appointed at the university in all majors. Faculty members from other countries which make up to about more than 20 percent of the total number of teachers do not have such a mentoring support. The workshops and trainings conducted by the center are on general teaching approaches and mainly in Arabic language.

It is the Quality and Development Unit at the ELI, Women Main Campus (WMC), that conceived the idea of mentoring, and started it with limited resources and implemented it in its true essence. The beneficiaries of this mentoring program are the faculty members, both the Saudis and non- Saudis. The beneficiaries of this mentoring program are the faculty members both the Saudis and non-Saudi. It provides professional development training services for its members with a prime aim of equipping them with the basic teaching skills and guiding them overcome the difficulties they might encounter in the classroom.

Nevertheless, the early mentoring program at the ELI was introduced in 2014. The primary purpose of this program was to support newly recruited faculty members to embrace the new ELI academic culture. The mentoring committee launched it under the Professional Development section. The main duty of this committee was to match mentors with mentees for peer observations; newly appointed teachers observed their mentors in the classrooms. With the expansion of the ELI and the need for more professionally developed faculty, the program was reviewed, modified and restructured under the supervision of Quality \& Development Unit.

\subsection{What is Mentoring?}

Mentoring is often defined as a professional affiliation in which a veteran (a mentor) facilitates and helps another person who may be an early learner (a mentee) in grooming specific skills and understanding in order to boost up the latter's professional and personal development and growth (Cutler, 2014). It is, basically, the association between the two persons in which the new teacher's inquisitiveness and craving to advance is supported and assisted by the mentor's proficiency. Mentoring helps teachers in their professional growth since it offers mentees with useful support that helps them achieve self-confidence, problem-solving skill, and implement critical thinking skills to situations affecting student learning (Wang and Odell, 2007).

Thus, in the course of mentoring, two main parties are concerned, namely a mentor and a mentee. First, the word mentor refers to any caring person who develops a continuing, one-on-one relationship with someone in need. Usually, a mentor motivates, inspires, encourages, listens carefully, gives wise pieces of advice, advocates, and acts as a role model, shares information and experience (Ehrich, Hansford \& Tennent, 2004). More particularly, a mentor is someone who affords professional assistance to a novice over some time. A mentor, who is a specialist to help a mentee extend his or her career, establishes the career-related role as a coach and offers advice to enhance the mentee's professional achievement and improvement. In so doing, the mentor establishes and evolves a mutual trust, respect, support, and collegiality. Second, a mentee is someone who receives support and advice about their profession by a mentor (a more experienced person). An ideal mentee is a new hire during the first year of employment, and a prospective mentee is the one who identifies her/his goals and objectives. The primary task is to play an active role in the mentoring relationship by understanding that the ultimate end is nothing but professional growth. Besides, a mentee can be an experienced teacher who also seeks help and wants to update her/his knowledge in their current position. Such teachers may have been transferred to a new campus where culture and procedures are different from those of the previous workplace. Hence, it is required a well-built affiliation between the mentor and the mentee, based on personal and professional commitment (Bjerkholt, 2013; Richter et al., 2011).

\subsection{ELI's Formal Mentoring Program}

The modified and restructured Mentoring Program was formally started in the 1st module of the academic year 2017-2018. The mentoring team for this program was carefully selected; it included a supervisor, a coordinator, members, and mentors. The formal Mentoring Program aims to provide support for ELI teachers to create an opportunity for new faculty members to learn about the ELI educational and cultural settings as well as 
administrative policies. The program also provides guidance and help to the ELI in-service teachers who need assistance to develop solutions to some classroom problems. The steps adopted by the program help ELI faculty to fully enhance their potential and maximize their professional growth. Hence, it was designed to be a resource for all teachers who were facing challenges in certain areas of their teaching or who simply would like to explore how they could further refine and improve their teaching.

The Mentoring Program Committee is the basis of any efficient mentoring program. It defines the capacity of the plan, selects materials and criterion to be used, analyzes applications and pairs mentees with suitable mentors, maintains records of the progress of each mentoring relationship, responds to complaints about incongruous pairings, and keeps roadmap of the program over time. Mentoring Committee sets up operational goals to shape the workforce of the future and to meet the Institute's strategic goals and objectives. The goal is to ensure that ELI has high-quality teachers in every classroom. It also strives to provide influential reflective teachers and to create a professional growth environment. This will sustain and encourage novice teachers and other faculty members through a climate of collaboration. The primary purpose of the mentoring program is to provide a structured framework for the improvement of teaching practices through face-to-face mentoring and coaching, discussions, workshops/ intensive training sessions and the innovative ideas to obtain operational goals of the mentoring committee. It is also part of the mentoring program's objectives to provide a unique opportunity for experienced teachers to impart some of their knowledge, experience and wisdom to novice teachers.

The mentoring committee develops a framework to run the mentoring program successfully, that consists of three main stages: development, implementation, and evaluation. The objective of the development stage is to lay the groundwork for the implementation of the formal mentoring program. The implementation stage focuses on defining expectations, orientation/information sessions, and on-going training sessions. During this stage, mentors and mentees must be made aware of the expectations of the program and set goals against which the program can be evaluated in the future. The purpose of the evaluation stage is to maintain continuous feedback so that problems can be identified and changes made accordingly. The following section further explains the composition and machination then the execution and finally, the evaluation of the current FMP.

\subsubsection{FMP Composition and Machination}

a. Setting Goals: Any well-planned and the well-executed program begins by developing goals and raising questions about the purpose and the time to achieve it, setting the goals provide direction and establishing accountability, and a means for measuring progress. At the design and planning stage, the focus was to design the parameters for the program. The mentoring committee set the goals and objectives of the mentoring program and established policies and procedures that reflected program decisions and practices that everyone followed.

- Mentoring committee designed activities for the academic sessions 2017-2018 and 2018-2019. Each mentor-mentee pair conducted two one-to-one mentoring sessions per semester in an academic year.

b. Recruiting Mentors: The number of mentors always depends on the program's goals and design. As the mentoring program at the ELI was designed to facilitate novice and in-service teachers, the committee set the mentor's selection criteria. Following qualifications and qualities for mentors, the considerations were:

- The candidate should have at least three years of experience in the same educational settings, and meet all the qualifications of her job category such as required qualification or certification

- The candidate should be an experienced professional and passionate in supporting and coaching novice and in-service teachers for their professional growth and career development

- The candidate should be familiar with the ELI rules and policies.

Mentors need the guidance of clear roles and tasks for which they are responsible (Rikard \& Banville, 2010). Ingersoll and Strong (2011) asserted that the role is a description of what a mentor is to be like; that is, the kind of person he or she must be to be effective. Mentors are experienced teachers who share their knowledge with less experienced teachers and gently guide them to enhance their practice. Here are a few roles and responsibilities set by the mentoring committee for a mentor:

- Continue to teach while serving as a mentor (no reduced workload)

- Understand the typical needs and challenges of the novice and in-service teachers, and ready to assist them in identifying personal strength and planning for further professional growth.

- Develop and use a variety of strategies to assist the novice and in-service teachers.

- Encourage and support the acculturation of the mentees into the ELI. 
- $\quad$ Prepare and implement a joint mentorship growth plan with the mentees.

- Maintain a relationship with the mentee who should be consistent with the Code of Professional Conduct.

- Be a 'Model' and demonstrate effective teaching strategies.

- $\quad$ Assist the mentees with curriculum and instructional planning.

c. Matching Mentors with Mentees: Mentoring relationships can be formal or informal. Informal mentoring relationships, the mentors and the mentees are paired by another party, such as the management of an organization, for a predetermined time. There is little or no involvement of the participants in the selection process of matching the mentors and the mentees within these programs (Hallam, Chou, Hite, \& Hite, 2012). The leading constituent to a thriving match is the yearning and eagerness of both individuals to contribute, to correspond, and to learn. Mentees were asked to fill out the need analysis survey form. Mentors were also asked to fill out a concise application narrating their interests. Based on the information presented by mentors and mentees, their common interests, goals, or other criteria (e.g. professional expertise), program's goals, expectations, and commitments provided a solid foundation for matching.

d. Toolkit for Mentors and Mentees: Toolkits were designed for mentors and mentees to develop commitment and accountability mechanism to crystalize the mentoring process. To properly manage the mentoring program, the following documents were designed and shared with all mentors and mentees.

\section{Contents}

\section{Contents}

Mentor's Toolkit

Menee's Toolkit

- Follow-up Form

- Mentor's Application Form

- Confidentiality Agreement

- Mentoring Log

- Mentee's Action Plan

- Mentor's Benefits

- Roles and Responsibilities of Mentors

- How Mentoring will Take-place?

- Giving Feedback Checklist for Mentors

- Frequently Asked Questions
- Follow-up Form

- Mentoring Agreement

- Confidentiality Agreement

- Mentoring Log

- Mentee's Action Plan

- Mentee's Benefits

- Roles and Responsibilities of Mentees

- How Mentoring will Take-place?

- Receiving Feedback Checklist for Mentees

- Frequently Asked Questions

e. On-going Training. After completion of the matching process, a plan of in-house workshops/training sessions and group discussions was designed for the professional development of mentors and mentees (novice $\&$ in-service). According to the mentor's selection criteria, each mentor would have to conduct a workshop on the chosen topics. Two group discussion sessions were conducted in each academic year. A research article selected by the head of the mentoring committee was sent to all mentees and mentors prior to each group discussion session.

f. Follow-up. On-going quality improvement is a guarantee of an effective mentoring program. How well we serve ELI teachers depends on how accurately we assess our program's success and identify areas that need improvement. Mentoring committee designed a follow-up plan and assigned committee members with matched mentors and mentees to follow-up their mentoring activities.

g. Accomplishment. Offering acknowledgement for noteworthy contributions and accomplishments is a significant element of a vigorous, secure and worthwhile mentoring atmosphere. Little things - a pat on the back, the encouragingly mentioning of one's name - do matter. Both public appreciation and private esteem for a job well-done enhance spirits, promote team spirit and elevate retention rates across the board. To make this program successful, the committee designed criteria to reward the mentors and mentees on successful completion of the mentoring program.

\subsubsection{FMP Execution}

Proficient and regular daily operations are essential for the achievement of any mentoring program. How fine and in a befitting manner, the participants involved in the program perform their responsibilities can signify the difference between disarray and steadiness, perplexity and unambiguous expectations, enthusiasm and compliance. 
At the operational stage, the mentoring committee conducted orientation sessions for mentors and mentees separately. Formal mentoring sessions were scheduled according to the defined criteria, expectations and objectives of the mentoring program.

Workshops and training sessions were conducted by mentors and invited speakers according to the scheduled plan. Two group discussions were conducted on the given research topics. According to the plan, the coordinator of the mentoring committee conducted an intensive one-day Mentoring training session for the mentors and mentees.

\subsubsection{FMP Evaluation}

Once the mentoring program has been positioned for some computable time period, devotees and participants must tackle the question of whether it's a valuable expenditure of time and endeavour. To accomplish that, the Mentoring Committee conducted a mid-point mentoring program evaluation survey from mentors and mentees at the end of the first semester of each academic year. Committee also conducted a final evaluation of the mentoring program at the end of each academic year. In addition, the committee conducted two focus group sessions with mentors and mentees separately to assess the usefulness of the program. The coordinator of the committee developed qualitative and quantitative reports to decide if the objectives of the program have been attired.

\subsection{Research Questions}

The purpose of this research is to present an account of ELI's Formal Mentoring Program which was successfully conducted for the academic years 2017-2019, to determine the experiences of participating faculty members, fifty-one novice teachers, twenty-eight in-service teachers and twenty-six mentors who participated in the mentoring program. This study emphasizes the prospects of proper mentoring programs as a valuable and suitable professional development strategy in higher education organizations.

The research attempts to answer the following questions:

\section{How is mentoring employed for EFL instructors at the ELI?}

2. What are the benefits of FMP in terms of their professional development, as perceived by ELI Instructors?

3. What are the challenges as perceived by the ELI Instructors?

\section{Literature Review}

Mentoring has been the spotlight of much consideration in the latest literature on initial teacher education and induction, that is why it has become a "foundation stone" of mutual accomplishments between universities in the facilitation of teacher development. Charlotte Danielson (1999) affirmed that mentoring assists novice teachers accept their new challenges; through insightful activities and expert conversations, they develop further their teaching practices as they presume thorough responsibility for a class. Danielson also concluded that mentoring promotes the professional growth of both new teachers and their mentors. Suitable training for the mentor's stretched teaching role and improves the value of a mentoring program. It is also worth noting that the simple presence of a mentor is not adequate; the mentor's knowledge of how to help new teachers and skills in providing direction is also decisive. Through a formal mentoring program, trained mentors assist novice teachers plan lessons, support them in collecting information about best practices, examine and monitor the new teachers' classes, and give an opinion. The novice teachers replicate on their practice and implement what they have learned to prospective lessons. In an analysis of the early effect of the program, Barbara Storms, Jean Wing, Theresa Jinks, Kathleen Banks, and Patricia Cavazos (2000) assessed that most of the teachers said that mentoring played a momentous function in the professional expansion of the new teachers. Particularly, the program's plan supported new teachers sharpen their practice-planning lessons, for example - and replicate on the efficacy of their instruction. Mentors also discovered that working with novice teachers affianced them in reflection about their own instructional practices.

Even though the objectives and targets of a mentoring relationship may be at variance according to context, all excellent mentoring partnerships engage the transfer of knowledge between a less experienced individual (the mentee) and the more experienced mentor. Mentors can afford insight and expertise to maintain the mentee's individual development and maturity (Allen and Eby, 2007). Formal mentoring programs must coherent to mentee hopes and offer tools to enable the mentee to reach his/her explicit goals. This is a significant differentiator between informal and formal mentoring program frameworks. Without necessary and deep accountability, it may be complex to construct the same point of substantial outcomes within a definite timeframe.

Additionally, as the compassionate presence of the mentor and relatedness emerge to be significant association extents impacting constructive youth improvement, the mentor-mentee connection may also be examined from the 
standpoint of attachment theory (Van Dam et al. 2018). Numerous research studies propose that several factors, such as rate of recurrence or constancy of relationship between mentors-mentees or point of continuing programme support, may affect youths' and mentors' discernments of associational worth or counterpart coordination (Martin \& Sifers, 2012; Larose et al., 2015; Zhou et al., 2018). Conventionally, it is supposed that mentoring is carried out face to face at the place of work. Nevertheless, presently, it has been carried out virtually also (Parlo, Allen and Rowan, 2017).

During the last twenty years, a formal mentoring program in higher education has been launched to assist new staff, and now the focal point has extended to developing research. Formal mentoring programs have a defined structure and clear guidelines and objectives. Informal mentoring programs do not have clear guidelines and structure and may not have clear objectives. There is a need to make it perfectly clear that mentoring is not coaching, which is a formal relationship focused on improving a specific behaviour or performance area to resolve work issues or handle aspects of the job. The coach is often an external individual or an individual's direct supervisor. Formal mentoring programs are associated with a plethora of benefits for mentors, mentees, and their organizations. For example, the benefits for mentees are professional development and a better understanding of organizational culture, while the primary benefits for mentors are developing a new awareness of other perspectives and developing leadership skills. According to the Association for Talent Development (ATD) 2017, 71 per cent of Fortune 500 organizations, in one way or the other, have formal mentorship programs, whereas many more bear informal initiatives.

Mentoring offers important and remarkable advantages to organizations. According to the Association of Talent Development (ATD), a well-made mentoring program can:

- Groom prospective leaders

- Assist personal and professional development

- Convey modern and new skills

- Promote vital organizational knowledge

- Enhance workplace commitment and self-esteem

- Heighten employee retention and faithfulness

- Offer a valuable onboarding tool

Mentoring also provides insightful advantages for mentees. Mentoring software firm research conducted by River (2015) transpires that 90 per cent of workers participating in a mentoring program informed that it facilitated them in developing a constructive relationship with another individual in the organization; 89 per cent reported it permitted them to contribute to the triumph of their organization, and 94 per cent opined that a mentoring program revealed an organization's commitment to present career options and opportunities. Eighty-three per cent affirmed that their mentoring experience certainly inclined their aspiration to stay at their organization.

According to Delaney (2012), studies have shown that mentoring relationships can inflict a positive impact on mentees' early teaching skills. For example, in their study conducted about novice teachers in England, Malderez, Hobson, Tracey, and Kerr (2007) collected data via questionnaires and face-to-face interviews revealing that most novice teachers commended their mentors for enhancing their self-confidence, offering support for classroom management, and affording guidance on time and workload management.

The eminence of a formal mentoring program has been because of an expansion in the understanding of how newly inducted teachers learn and gain practical knowledge about the teaching profession. Nevertheless, the origin of mentoring as a professional learning approach has also been accredited to the junction of economic policy and workplace learning theory. Mentoring seized authenticity as a professional learning strategy, and at the simultaneously, it appeared to present a cost 'solution' in training and development for teachers.

The formal mentoring program has usefulness and advantages for all involved. It is an ingrained idea being conducted in many professions, like teaching by many organizations. According to McKimm, Jollie, and Hatter (2003), mentoring programs can assist and maintain:

- predominantly recognized groups

- developmental and work-based learning programs

- individuals or organizations through transformation or evolution

- Improved usefulness of organizations and individuals 
While there is not a divergent definition, mentoring can be illustrated as an interpersonal affiliation. This can take the figure of a more higher-ranking or qualified person cooperating with and helping a junior or less experienced person (Clutterbuck, 1992) or in a more comprehensive idea where the mentor, of identical or alike rank, goes beyond guidance and sponsorship and works with the mentee to afford support to construct self-confidence and competencies to develop working relationships. The latter notion seems to sum up the foundational insights of the most current analysis of mentoring and which has been the force for much of the existing awareness (Gibb, 1994).

Roberts (2000:145) identified some necessary characteristics that characterized mentoring, such as, "an accommodating relationship; a facilitating process; a teaching-learning instructive practice; an insightful process; a career growth process; a pompous process; and a function constructed by or for a mentor". He also stated, "Mentoring is a multifaceted, social and psychological activity" (162).

Mentoring is extensively acknowledged as an imperative attachment to teaching because it influences and nurtures the scholarly development of learners. Mentoring is also decisive for pre-service teachers and newly eligible teachers' career maturity within the school. The teacher mentor has an effect and impression on the mentee's practices (Hobson, Ashby, Malderez, and Tomlinson, 2009), predominantly through discussing practices, modelling teaching and submitting feedback (Clarke, Triggs, and Nielsen, 2013).

\subsection{Benefits of Mentoring}

The research recommended that mentoring is an essential and effectual structure of supporting the professional advancement of pre-service teachers (Carter \& Francis, 2001; Franke \& Dahlgren, 1996; Marable \& Raimondi, 2007; Su, 1992). More explicitly, McIntyre and Hagger (1996) documented a number of advantages of mentoring for novice teachers that include abridged outlooks of segregation, amplified poise and self-respect, professional progression, and enhanced self-reflection and problem- solving capabilities and skills. The advantages of mentoring which may be most common feature amongst research findings share the stipulation of poignant and professional maintenance, which has been demonstrated to be supportive in enhancing the confidence of novice teachers, allowing them to put complex experiences into standpoint, and increasing their spirits and job satisfaction (Bullough, 2005; Johnson, Berg, \& Donaldson, 2005; Lindgren, 2005; Marable \& Raimondi, 2007).

The review of past literature also transpires the effect of mentoring on increasing the efficiency of beginning teachers, most remarkably their attitude and classroom management proficiency and capacity to handle their time and workloads (e.g. Lindgren, 2005; Malderez et al., 2007; Moor et al., 2005). Typically, mentors were observed to enjoy a unique position in the professional growth of trainee teachers, assisting them to become accustomed to the rules, principles and hopes attached with teaching (Bullough\& Draper, 2004; Edwards, 1998; Feiman et al., 1992; Wang \& Odell, 2002). Mentors have also been observed to be acquainted of their mentees, through the involvement in mentor training courses, imparted by university tutors (remarkably those concerned in university-school joint venture ITP programs), and more commonly, from opportunities to converse with others about teaching and learning in common or about their mentees' or their own teaching in particular (Hagger \& McIntyre, 2006; Lopez-Real \& Kwan, 2005).

The review of past literature also proves that mentoring benefits mentors. For example, the evidence afforded on the accounts of mentors recommended that mentoring beginning teachers confidently impacted their professional and personal growth. (e.g. Hagger \& McIntyre, 2006; Yeomans\& Sampson, 1994).

In terms of the upshots of mentors' participation in mentoring, numerous studies (e.g. Abell, et al., 1995; Lopez-Real \& Kwan, 2005; Simpson et al., 2007) cited mentors' references to acquiring 'new ideas' and 'new perspectives. More particularly, mentors have reported learning innovative and better teaching styles and strategies, improving their knowledge and use of Information and Communication Technology (ICT) (Davies et al., 1999; Lopez-Real \& Kwan, 2005), developing their communication skills (Moor et al., 2005), becoming more insightful (Davies, et al., 1999); and becoming well-informed about beginner teachers' and others' professional improvement demands (Lopez-Real \& Kwan, 2005; Moor et al., 2005). Some researches have submitted to mentors sensing at peace when their thoughts are justified by university tutors (Lopez-Real \& Kwan, 2005; Simpson et al., 2007), feeling less lonely as teachers and taking pleasure in the improved teamwork related to mentoring (Hagger \& McIntyre, 2006; Simpson et al., 2007), and reporting amplified confidence in their own teaching and enhanced relationships with pupils and colleagues, (Hobson et al., 2009), and being 'more cooperative', 'more challenging with colleagues' and 'more forbearing with pupils' (Bodoczky \& Malderez, 1997; Davies et al., 1999).

Previous research studies transpired that several mentors would obtain fulfilment and pride from undertaking the mentor position, particularly through seeing their mentees thriving and progressing and noticing proof of their effect on mentees' progress and their teaching (Beck \& Kosnick, 2000; Hagger \& McIntyre, 2006). It has also been 
established that mentoring can guide to an evaluation of mentors' teacher distinctiveness and professional standing and an enhancement in their self- worth, resulting from the liability involved and in the same way improved appreciation in the professional community (Bodoczky \& Malderez, 1997; Wright \& Bottery, 1997), while some mentors have informed 're-vitalization of their fervour for teaching' (Moor et al., 2005), becoming 're-energized' or re-engaged' with the occupation (Hobson, et al., 2007) and are more devoted to teaching (Bodoczky \& Malderez, 1997).

A few studies recommended that participation in mentoring has facilitated each teachers' vocation setting up and career evolution by, for example, assisting them to recognize their potentials and preferences (Tauer, 1998), heling in getting an expansion of their liability for assisting the career advancement of other coworkers, or utilizing their professional skill as mentors to follow professional credentials (Moor et al., 2005).

Moreover, a few studies revealed advantages of mentoring for institutions and educational system, comprising more convinced and competent beginning teachers and more dedicated and passionate mentors; who would be expected to generate knock-on benefit for these teachers' students and schools, remarkably as improved students learning (Moor et al., 2005). The substantiation on this exacting effect is nevertheless restricted because of, to the researchers' understanding, the intricacy of researching it. There is a flourishing pile of confirmation, however, chiefly from the USA, which informs us that mentoring programs for beginning teachers encourage increased retention and constancy. In other words, teachers who have been given mentoring facility have been observed to be hardly seen to quit teaching job and less expected to shift to other schools within the occupation (Ingersoll \& Kralik, 2004; Johnson et al., 2005; Smith \& Ingersoll, 2004). It is also probable that schools, as well as educational set-ups, may gain from the increased retention of the teacher-mentors who are more certain and loyal as a consequence of their involvement in mentoring, which is one of the objectives of some mentoring programs, despite the fact that again there is restricted undeviating proof of this up till now.

In their conclusive report about the appraisal of the Pilot Professional Development Program for Teachers Early in their Careers in England, Moor, et al., (2005) proposed several added benefits to institutions in broad-spectrum, of their involvement in this sort of mentoring program. For example, it was observed that, through mentoring associations and the raised profile of beginning teachers and of early professional development activities within the institution, faculty came to be acquainted of each other better, which guided to their augmented alliance and satisfaction. In addition, some mentors are attached to the program asserted that highly experienced teachers had also started to come to them for individual assistance and advice on explicit areas and/or their own professional requirements, suggesting that the program had promoted a more developed culture of professional development and assistance within participating institutions.

Mentoring may also fetch about unfavourable or unfavourable results for the mentor. This can present a wastage of the mentor's physical as well as intellectual resources (Bullough\& Draper, 2004), and, in some programs, the mentor should allot time from an already hectic teaching schedule. Studies have pointed out that mentors experienced feelings of disarticulation and loss of privacy (Koerner, 1992).

For this reason, it is sometimes concluded that mentoring is a lucrative method of training and grooming staff because mentors are capable of accomplishing their task in combination with their regular teaching job and there is no cost earned for outside training providers (Murray \& Owen, 1991). To date, though, there is available little empirical evidence to maintain (or refute) this assertion in the perspective of mentoring for beginner teachers.

\subsection{An Effective Mentoring}

While some 'conditions' would be more likely to assist the attainment of some mentoring objectives than others, a number of general findings have started to appear from the research concerning the factors which impact on the achievement or else of various types of mentoring programs across a range of contexts. These relate to (i) contextual support for mentoring; (ii) mentor choice and pairing; (iii) mentoring strategies; and (iv) mentor groundwork (Hobson, A. J et al., 2009).

Some other research studies have also concluded that thriving mentoring is reliant on the 'consent' to be mentored on the fraction of the beginner teacher-mentee (Little, 1990; Roehrig et al., 2008; Valencic Zuljan \&Vogrinc, 2007; Veenman et al., 2001), a topic over which policymakers and teacher educators may come out to have only restricted control. However, though research on this specific question is rare, there is a possibility that a mentee's eagerness and candidness to getting the most out of a mentoring affiliation will be inclined to at least some degree by the circumstance within which the mentoring takes place, the appropriateness and distinctiveness of the mentor assigned, and the homework received and strategies engaged by that mentor (Martin \& Rippon, 2003). 


\subsection{Contextual Support for Mentoring}

Research in past reflects that a variety of contextual factors impacts the accomplishment of mentoring programs and mentoring relationships. The most reliable finding in this domain is that, other things being identical, mentoring is more likely to be successful where teacher-mentors are offered with extra discharge or non-contact time to facilitate them prepare for and carry out the mentoring role (e.g. Abell, et al., 1995; Lee \& Feng, 2007; Robinson \&Robinson, 1999), while thriving mentoring is further appreciated and commended where timetabling permits mentors and mentees to assemble together during the school day (e.g. Bullough, 2005). Some studies have also reported that mentoring is more likely to direct to constructive outcomes where mentors obtain reward and/or some other form of enticement or acknowledgement for their work (Abell et al.,1995; Evans \& Abbott, 1997; Simpson et al.,2007); where it takes place in environments which are comparatively free from extreme emphases on externally resolute aims and agendas such as narrow criteria for teaching practices (Edwards, 1998; Gay \& Stephenson, 1998; Yusko \& Feiman Nemser, 2008); where mentors are involved in the plan and assessment of and are devoted to, the broader (ITP, orientation or early professional development) programs of which mentoring is a part (Evans \& Abbott, 1997); and where such programs are coherent and not characterized by 'fragmentation' (Goodlad, 1990) between various (e.g. school-based and university-based) contributors (Hascher, et al., 2008).

Additionally, beginner teacher mentoring is probably to be flourishing where it is practised in schools which are characterized by mutually respectful, friendly and erudition cultures (Edwards, 1998; Lee \& Feng, 2007); where both mentors and mentees have the inclination to support outside of the mentoring relationship, like from other teachers in the school or from outside networks of peers (Whisnant et al., 2005); and where mechanisms subsist that make possible mentees and mentors to commence the organization of a substitute pairing, without culpability being inflicted to either party, where they sense that the relationship is not (or is no longer) prolific (Association for Supervision and Curriculum Development, 1999).

\subsection{Mentor Selection and Matching}

Multiple studies put forward that the triumph of beginner teacher mentoring is, in part, a purpose of the ways mentors are chosen and paired with mentees. Mentors should be efficient practitioners who are able to model good professional practice (Foster, 1999; Roehrig et al., 2008), and it is significant that mentees have 'professional respect' for their mentors, which requires that, in the mentees' eyes at least, their mentors own ample knowledge and experience of (for example) teaching and their subject specialization (Abell et al., 1995). Yet being an experienced and successful teacher, and being acknowledged as such, is a compulsory but not enough condition for being an active mentor - not all good teachers make good mentors, while not all good mentors make good mentors of all beginning teachers (Evertson \& Smithey, 2000; Johnson, 2004; Schmidt, 2008; Yusko \& Feiman Nemser, 2008). Effective mentors must also be keen and able to 'make their work public' and make unequivocal the factors underlying their classroom practices (Simpson et al., 2007); and they must be helpful, amenable, nonjudgmental and dependable, have affirmative conduct, and hold good listening skills and the aptitude to empathize, as well as the motivation and ability to take an interest in beginning teachers' work and lives (Abell et al., 1995; Rippon \& Martin, 2006; Yeomans\& Sampson, 1994). Importantly, mentors should also desire to do the job and be devoted to the work of mentoring (Abell et al., 1995; Lindgren, 2005; Wildman et al., 1992); the more that the mentoring relationship results from a 'forced marriage', the less likely seem its chances for success.

For similar reasons, a research study has also concluded that mentoring is more likely to be successful where decisions about mentor-mentee pairings take account of mentees' strengths and precincts, and where the mentor and mentee get along both personally and proficiently (Abell et al., 1995).

Several studies have observed that, like all kinds of teaching, mentoring is most effectual where it is vigorous for rationale and discusses and is approachable too, the requirements of the mentee/learner. This suggests that mentors of trainee teachers should revere their mentees as adult learners, considering their learning methodologies, and guaranteeing that the policies implemented to maintain their learning are receptive to their worries and apt to their present phase of development (Foster, 1999; Lindgren, 2005; Valencic et. al., 2007). Many researches imply that, at an early phase in the mentoring affiliation, mentors should search for to facilitate mentees to discover and question critically their notions of teaching, of imparting education and of mentoring (Edwards, 1998; Feiman et al., 1989; Rajuan, et. al., 2007), which can otherwise propose obscured barriers to their subsequent learning and development (Sugrue, 1996; Korthagen et al., 2001; Wubbels, 1992). This practice should include a clear discussion of the quality and advantages of various forms of manifestation (Lindgren, 2005). Mentors should also try to find conformity on the individual aims, and targets of the mentee and the objectives of the mentoring relationship, and should occasionally re-examine, assess and (where appropriate) modify these objectives and 
goals (Lindgren, 2005; Stanulis \& Weaver, 1998).

Even as the degree to which mentors can deal with mentees' individual requirement is a significant aspect in the achievement or otherwise of mentoring, research has also recognized several mentoring aspects, policies and procedures which have been approved to be effectual across various contexts. First, efficient mentors supply their mentees with exciting and psychological facilitation, and make them realize welcome, acknowledged and integrated (Feiman, 2001; Hascher, et. al., 2004; Maynard, 2000; Rippon \& Martin, 2006). Secondly, successful mentors spare time for their mentees: they have usual discussions with them and are accessible for casual discussion at other times (Adey, 1997; Harrison, et. al., 2006; Johnson, et. al., 2005). Thirdly, effective mentors permit their mentees an apt level of self-sufficiency to form opinions and recommendations and to extend their teaching styles (Feiman, 2001; Foster, 1999; Harrison et. al., 2006). Fourthly, several studies have established that one of the most appreciated perspectives of the work undertaken by mentors is lesson observation (both of and by the mentee) with successive analysis of the processes implicated (e.g. Foster, 1999; Heilbronn et al., 2002; Hobson, 2002). Mentors' observation of the lessons of their mentees is inclined to be most prized where its objectives are approved in a pre-observation conference, and where the post-observation conference: (i) is conducted in a responsive, non- threatening way; (ii) focuses on definite aspects of mentees' teaching; and (iii) offers an opportunity for authentic and positive dialogue between mentor and mentee which comprises shared investigation of the professed strengths and weaknesses of the mentee's teaching, discussion of the likely effects of observed teaching measures, and the progress of ideas which might facilitate the mentee surmount any issues, shortcomings or flaws (Jonson, 2002; Martin \& Rippon, 2003; Schmidt, 2008). Finally, research shows that valuable mentors guarantee that their mentees are adequately challenged (Edwards, 1998; Harrison, et. al., 2006; Valencic \& Vogrinc, 2007) and suitably educated about and scaffold into deeper levels of thinking and manifestation, markedly about teaching and learning (Feiman, 2001; Franke \&Dahlgren, 1996).

\subsection{Mentor Preparation and Support}

A number of studies recommended that mentors would be more likely to utilize valuable mentoring strategies where they have undertaken an appropriate program of mentor preparation (e.g. Crasborn, Hennisson, Brouwer, Korthagen, \& Bergen, 2008; Williams \& Prestage, 2002; Valencic \& Vogrinc, 2007). Bullough (2005) concluded from his research study of 'being and becoming a mentor', that mentor preparation needs to go afar 'training', conventionally conceived as behavioural instilling without insight (Tomlinson, 1995) and should contain planned strategies to aid individuals in growing their identities as mentors. One method by which this might be attained, Bullough (2005: 153) proposes, is via their attending seminars, 'organized around the practice of mentoring', together with other teacher-mentors and university-based teacher educators. Such seminars could function as 'affinity groups', serving to overcome mentor seclusion, facilitating the growth of a shared discussion for mentoring, and enhancing mentors' skill development through dialogue about mentoring practice and pedagogy (cf. Carroll, 2005; Graham, 1997; Orland, 2001). Other studies have highlighted the significance of advising mentors towards proper research that will strengthen their mentoring activities (Evans \& Abbott, 1997), of helping them to comprehend the worth and possible benefits of discussing pedagogical concerns with beginning teacher mentees (Lindgren, 2005); and of mentor preparation activities aimed at the development of their interpersonal skills (Rippon \& Martin, 2006) or their capability to excite mentees to reproduce on their actions (Crasborn et al., 2008; Dunne \& Bennett, 1997).

\section{Methodology}

\subsection{Data Collection}

Mentoring Committee maintained a high level of formative evaluation through such means as focus group reports, mid-point and final evaluation surveys. This study used a mixed-method approach to investigate the implementation and impact of a formal mentoring program for EFL instructors at the ELI. The research method of data collection employed using both qualitative and quantitative approaches, including surveying mentee and mentor teachers on a five-part Likert scale and interviews with experienced mentors; besides to a focus group interview with the participants. The focus group interview was thematically analyzed

\subsubsection{Questionnaire for the Quantitative Data}

Although mid-point and final term evaluation surveys were conducted at different times, a series of questions that were asked in these two surveys remained mostly unchanged during the years. Data was collected through a 10-question survey to seek the novice teachers and mentor teachers' opinion about the implementation of the current formal mentoring program at the ELI and its impact on them. The questionnaire items were placed on a 5-point Likert scale ranging from "strongly disagree" to "strongly agree". This was collected from 77 participants, of whom 51 were novice teachers and 26 mentor teachers at the ELI. 


\subsubsection{The Qualitative Data}

For the qualitative data, the researchers conducted two different techniques, namely a focus group and semi-structured interviews. First, a focus group was used to obtain a detailed opinion from the mentees and mentors about the effectiveness of a formal mentoring program in their professional development and classroom teaching problems and concerns. It contained close-ended questions that let the researchers have control. The use of focus group discussion in this study was to provide access to particular issues that could not be directly observed, such as feelings, intentions, thoughts, or beliefs (Denzin,1988:110; Merriam, 1998:58). Second, semi-structured interviews were conducted by mentors and mentees. Interviews provided the participants with an opportunity to select, reconstruct and reflect upon details of their experiences within the specific context of their lives (Ohata, 2005, p. 141).

\subsection{Data Analysis}

The results were analyzed using percentages and measures of central tendency as detailed below.

\subsubsection{Analysis of Quantitative Data}

For the quantitative data, mid-point evaluation survey and final term evaluation survey were conducted through a 10-question survey.

\section{Mentors' Mid-point and Final Evaluation}

After successful completion of ELI's Formal Mentoring Program, the participating members (26 mentors and 51 mentees) submitted their responses in Mid-point Evaluation (end of the first semester) and Final Evaluation on a five-part Likert scale such as: 1. Strongly Disagree. 2. Disagree, 3. Neutral, 4. Agree, 5. Strongly Agree. Table-1 of mentors' mid-point evaluation survey responses illustrated the analyzed achievements of the mentoring program which shows high results of achievements in accordance with the ten statements indicating the mean from $88 \%$ to $95 \%$ with high mean level.

Table- 2 of mentors' final evaluation survey responses based on ten statements indicate that the least mean per cent is $89 \%$ and so as the highest is $96 \%$.

Almost all the mentor-participants felt empowered and expressed their utmost satisfaction of the mentoring program as they acquired much knowledge of teaching methods and classroom management. They also much enjoyed the workshops and learning about other teachers' strategies for approaching various classroom challenges and opportunities.

Table 1. Mentors Mid-Point Evaluation of the Mentoring Program at ELI

\begin{tabular}{|c|c|c|c|c|c|c|c|c|}
\hline S. No. & Statements & $n$ & 1 & 2 & 3 & 4 & 5 & Mean \\
\hline 1 & $\begin{array}{l}\text { The Support I get from the mentoring } \\
\text { program makes me a better mentor. }\end{array}$ & 24 & - & - & 2 & 5 & 17 & 4.63 \\
\hline 2 & My mentee and I have similar interests. & 24 & - & - & 1 & 12 & 11 & 4.54 \\
\hline 3 & $\begin{array}{l}\text { My mentee makes me aware of her } \\
\text { problems or concerns. }\end{array}$ & 24 & - & - & 1 & 9 & 14 & 4.67 \\
\hline 4 & $\begin{array}{l}\text { My mentee does not avoid talking with } \\
\text { me about problems or issues. }\end{array}$ & 24 & - & - & - & 10 & 14 & 4.58 \\
\hline 5 & $\begin{array}{l}\text { My mentee seems comfortable when I } \\
\text { offer help. }\end{array}$ & 24 & - & - & - & 6 & 18 & 4.75 \\
\hline 6 & I do not feel distant from my mentee. & 24 & - & - & - & 7 & 17 & 4.71 \\
\hline 7 & $\begin{array}{l}\text { I am sure that my mentee is getting enough } \\
\text { out of our match. }\end{array}$ & 24 & - & - & - & 10 & 14 & 4.58 \\
\hline $\begin{array}{l}8 \\
9\end{array}$ & $\begin{array}{l}\text { I feel comfortable when I'm with my mentee. } \\
\text { I feel like I am making a difference in }\end{array}$ & 24 & - & - & - & 7 & 17 & 4.71 \\
\hline 10 & $\begin{array}{l}\text { my mentee's performance. } \\
\text { I feel like my mentee and I have a strong } \\
\text { bond (are close or deeply connected). }\end{array}$ & 24 & - & - & - & 12 & 11 & 4.42 \\
\hline
\end{tabular}

Note: S.D:1. Strongly Disagree, 2: Disagree, 3: Neutral, 4: Agree, 5: Strongly Agree 
Table (1) describes the results gathered from the 10 closed-ended questions answered by mentors in the study questionnaire. Statement-1 of the questionnaire displays mentors' responses on the benefits of mentoring program. As shown in statement-1, a large majority of the participants (93\%) agreed with the notion that mentoring program made them better mentors. Mentor-mentee matching process is the most important event of any successful mentoring program. When asked if they had similar interests to benefit themselves of the mentoring program, the result $(91 \%)$ of the statement-2 proved that they strongly agreed to the statement. The result of statement-2 has proved that paired mentors and mentees were satisfied with the matching process and strongly agreed that they had similar interests for mentoring relationship. Moreover, when they were asked about their mentees' problems and issue, their comfort level to share their problems, the most of the participants (95\%) strongly agreed that their mentees felt comfortable during mentoring sessions and they shared their problems and concerns without any reluctance. In statement- 9 , over $88 \%$ of the mentors responded that they had developed mentees' abilities and provided support, knowledge, and guidance, which helped them to become more successful.

Table 2. Mentors Final Evaluation of the Mentoring Program at ELI

\begin{tabular}{|c|c|c|c|c|c|c|c|c|}
\hline S. No. & Statements & $n$ & 1 & 2 & 3 & 4 & 5 & Mean \\
\hline 1 & My mentee was accessible and available & 26 & - & - & 3 & 7 & 16 & 4.50 \\
\hline 2 & I had regular meetings with my mentee. & 26 & - & - & 4 & 5 & 17 & 4.50 \\
\hline 3 & My mentee respected my time and & & & & & & & \\
\hline & professional responsibilities. & 26 & - & - & - & 8 & 18 & 4.69 \\
\hline 4 & My mentee was concerned about academic & & & & & & & \\
\hline & problems and overcome the deficiencies. & 26 & - & 1 & 1 & 5 & 19 & 4.62 \\
\hline 5 & My mentee's behaviour and attitude was & & & & & & & \\
\hline & generally professional and courteous. & 26 & - & - & - & 5 & 21 & 4.81 \\
\hline 6 & I recommended my mentee for further & & & & & & & \\
\hline & professional or personal development activities. & 26 & 1 & - & 1 & 8 & 16 & 4.46 \\
\hline 7 & $\begin{array}{l}\text { The support I get from the mentoring program } \\
\text { makes me a better mentor. }\end{array}$ & 26 & - & - & 3 & 2 & 21 & 4.69 \\
\hline 8 & $\begin{array}{l}\text { The mentoring committee is accessible to talk } \\
\text { if any problem arises. }\end{array}$ & 26 & - & - & 1 & 5 & 20 & 4.73 \\
\hline 9 & $\begin{array}{l}\text { I learned new things and benefited personally, } \\
\text { professionally from the mentoring relationship. }\end{array}$ & 26 & - & - & 1 & 3 & 22 & 4.81 \\
\hline 10 & $\begin{array}{l}\text { I found this program to be well organized and } \\
\text { supported by Mentoring Committee. }\end{array}$ & 26 & - & - & 1 & 4 & 21 & 4.77 \\
\hline
\end{tabular}

Note: 1: Strongly Disagree, 2: Disagree, 3: Neutral, 4: Agree, 5: Strongly Agree

As shown in Table 2, the majority of mentors perceived the program to be successful, from $89 \%$ to $96 \%$ in agreement that the mentor-mentee pairs were suitable, mentoring trainings were well organized, and teaching resources were accessible. Mean scores for all statements were above 4 points on a 5-point Likert scale. A vast majority of the participants (90\%) agreed that their mentees always showed interest in mentoring sessions. They always showed professionalism and punctuality to attend professional development activities and face-to-face mentoring sessions.

The responses to statement-7 indicated that mentors believed the mentoring program helped them to become better mentors. When they were asked about their mentoring relationship and their personal and professional benefits, which they got from a mentoring program, most of the participants (95\%) strongly agreed that mentoring procedures helped them gain more knowledge about their academic work settings and in their personal and professional development. They learned more teaching skills from this program. Moreover, a majority of $(96 \%)$ participants strongly agreed that the program was well structured and productive. 


\section{Mentees Mid-point and Final Evaluation}

The responses from the mentees also showed positive feedback in most categories. All questions reflected the level of benefits of mentoring activities (PD activities/training sessions \& face-to-face mentoring sessions and classroom visits of assigned mentors). The responses of the participants represented that mentors were very committed and responsible. They were always concerned about their academic need and problems. The results of responses reflect that $94 \%$ of participants were fully satisfied with the mentoring relationship and mentors' voluntarily willingness for the mentees. The results showed that mentors helped their assigned mentees in their professional development and classroom problems. The results of statements illustrated that mentoring relationship familiarized the mentees with the ELI; directed the mentees to appropriate resources; mentor had used the mentee goal checklist; mentor had used a written action plan; had the mentor challenge the mentee to extend her abilities, and had the mentor observe a class. The result $93 \%$ of statement 9 showed the significance of mentoring program for the mentees as they found the mentoring relationship beneficial for her professional development and classroom management and activities.

Table 3. Mentees Mid-Point Evaluation of the Mentoring Program at ELI

\begin{tabular}{|c|c|c|c|c|c|c|c|c|}
\hline S. No. & Statements & $n$ & 1 & 2 & 3 & 4 & 5 & Mean \\
\hline 1 & My mentor has been meeting me on a regular basis. & 32 & - & - & 1 & 2 & 29 & 4.78 \\
\hline 2 & My mentor consistently anticipated my needs. & 32 & - & - & - & 6 & 26 & 4.72 \\
\hline 3 & $\begin{array}{l}\text { My mentor has fully engaged and committed to } \\
\text { our mentoring relationship. }\end{array}$ & 32 & - & - & - & 5 & 27 & 4.78 \\
\hline 4 & $\begin{array}{l}\text { My mentor has introduced me to instructional } \\
\text { approaches/strategies that I was not aware of before. }\end{array}$ & 32 & - & - & 1 & 7 & 24 & 4.66 \\
\hline 5 & My mentor is always willing to listen to me. & 32 & - & - & - & 4 & 28 & 4.72 \\
\hline 6 & $\begin{array}{l}\text { My mentor always expected me to bring up the } \\
\text { topics/ problems we discuss. }\end{array}$ & 32 & - & 1 & 1 & 3 & 27 & 4.66 \\
\hline 7 & My mentor has helped me to grow as a professional. & 32 & - & - & 2 & 4 & 26 & 4.66 \\
\hline 8 & $\begin{array}{l}\text { I am very satisfied with the level of support I am } \\
\text { continuing to receive from my mentor. }\end{array}$ & 32 & - & - & 1 & 4 & 27 & 4.63 \\
\hline 9 & $\begin{array}{l}\text { I learned new things about myself and benefitted } \\
\text { personally, and professionally from this relationship. }\end{array}$ & 32 & - & - & 1 & 2 & 29 & 4.81 \\
\hline 10 & Overall, my mentor is an asset and a benefit to me. & 32 & - & - & - & 2 & 30 & 4.78 \\
\hline
\end{tabular}

Note: 1: Strongly Disagree, 2: Disagree, 3: Neutral, 4: Agree, 5: Strongly Agree

As shown in Table 3, the majority of mentees perceived the program to be successful, with $93 \%$ to $96 \%$ in agreement that their mentors were always accessible and available, mentoring trainings were well organized, and teaching resources were accessible, mentors played a vital role in their professional performance. Mean scores for all statements were above 4 points on a 5-point Likert scale. As shown in Table-3, a vast majority of the participants (96\%) strongly agreed to the statement-1 that their mentors were always accessible and available to help them in their problems and concerns. Moreover, in statement-3, most of the participants (96\%) agreed that their mentors were good listeners. They listened to us and offered guidance to improve our teaching skills.

Regarding mentees' opinions on the mentoring relationship, the result, as illustrated in statement-9, shows that (96\%) of the participants agreed that mentoring relationship helped them gain more knowledge about their academic work settings. Their mentors run the mentoring sessions effectively. The behaviour and attitude of the mentors were appreciable. 
Table 4. Mentees Final Evaluation of the Mentoring Program at ELI

\begin{tabular}{|c|c|c|c|c|c|c|c|c|}
\hline & Statements & $n$ & 1 & 2 & 3 & 4 & 5 & Mean \\
\hline 1 & My mentor has been meeting me on a regular basis. & 51 & - & - & 6 & 13 & 32 & 4.50 \\
\hline 2 & My mentor consistently anticipated my needs. & 51 & - & 2 & 4 & 13 & 32 & 4.50 \\
\hline 3 & $\begin{array}{l}\text { My mentor has fully engaged and committed to our } \\
\text { mentoring relationship. }\end{array}$ & 51 & - & - & 4 & 12 & 35 & 4.69 \\
\hline 4 & $\begin{array}{l}\text { My mentor has introduced me to instructional } \\
\text { approaches/ strategies that I was not aware of before. }\end{array}$ & 51 & - & - & 8 & 19 & 24 & 4.62 \\
\hline 5 & My mentor is always willing to listen to me. & 51 & - & - & 2 & 11 & 38 & 4.81 \\
\hline 6 & $\begin{array}{l}\text { My mentor always expected me to bring up the } \\
\text { topics/ problems we discuss. }\end{array}$ & 51 & - & 2 & 4 & 16 & 29 & 4.46 \\
\hline 7 & My mentor has helped me to grow as a professional. & 51 & - & - & 6 & 12 & 33 & 4.69 \\
\hline 8 & $\begin{array}{l}\text { I am very satisfied with the level of support I am } \\
\text { continuing to receive from my mentor. }\end{array}$ & 51 & - & - & 5 & 8 & 38 & 4.73 \\
\hline 9 & $\begin{array}{l}\text { I learned new things about myself and benefitted } \\
\text { personally, and professionally from this relationship. }\end{array}$ & 51 & - & - & 4 & 11 & 36 & 4.81 \\
\hline 10 & Overall, my mentor is an asset and a benefit to me. & 51 & - & - & 4 & 12 & 35 & 4.77 \\
\hline
\end{tabular}

Note: 1: Strongly Disagree, 2: Disagree, 3: Neutral, 4: Agree, 5: Strongly Agree

As shown in Table-4, a vast majority of participants agreed with the support of their assigned mentors. The result of statement-5 has confirmed that a majority of participants were fully satisfied with their mentors' support and cooperation. The results proved the significance of the mentoring program for the mentee and mentors. The results of statements endorsed that mentor's commitment with mentoring relationship has played a vital role in the professional development of their mentees and other classroom teaching issues. The result $86 \%$ of the statement 4 also showed that mentors had helped their mentees in adopting modern instructional approaches and strategies that they were not familiar with before. A majority of the participants (93\%) personally and professionally benefitted from the mentoring program. The participants attended face-to-face mentoring and coaching sessions, attended workshops on different topics and also attended need-based training sessions and research-based intensive training sessions. In statement-9, (93\%) of the participants affirmed that mentors are the backbone of any successful mentoring program. They have significantly helped and support their mentees in classroom teaching and management issues. When they were asked about their mentors in statement-10, (92\%) of the participants strongly agreed that their mentors were an asset for them and they offered guidance and assistance to solve their problems and concerns at workplace.

\subsubsection{Analysis of Qualitative Data}

As shown in the questionnaire results and findings, participants provided mostly positive feedback about their mentoring experience at the ELI. According to the participants' feedback, the formal mentoring program facilitated new teachers to adjust in the culture of the English Language Institute. The Mentoring program also helped them in their professional development and classroom teaching problems and concerns. In addition to the quantitative feedback, focus group discussions with the participants were employed to collect data for the research. Focus group discussion data was also collected and thematically analyzed to understand better the process of mentoring, and its possible contributions in the professional development of the mentors, novice teachers and in-service teachers.

\section{The activities they did with mentor and the things they learned from mentors.}

As the underlying theme of the formal mentoring program was to facilitate the mentees (novice and in-service) in their classroom teaching problems, so many participants of the focus group discussion responded positively. In response to a question, the participants said,

"We met to talk about lesson planning, I sent her one of my lesson plans and she provided feedback, she sent me some extra lesson planning resources, we talked about the use of WhatsApp with the class". 
Another respondent of the study remarked,

"Introduced me to new technological apps/ sites for the classroom".

Respondent 3 of the study responded,

"I have learned from my mentor many skills and techniques that will help me to deliver the lesson clearly and precisely, such as: using modern techniques like mobile apps and visual aids; methods given to engage with students, and many more".

Respondent 4 of the study stated,

"My mentor is a wonderful and knowledgeable person but I understand that she had many responsibilities which prevented her from being very proactive regarding meeting with me. Overall it wasnot an issue because I am quite self-motivated, but I would have liked the opportunity to interact a bit more".

\section{What did you like best about the mentoring program?}

The question was raised in the discussion with the mentors and mentees as to what they liked best about the mentoring program. Mentors and mentees expressed their opinions in the discussions conducted by the researchers. When asked the question, one of the mentees responded,

"I like the atmosphere of the cooperative mentoring team. I greatly enjoy the workshops and learning about other teachers' strategies for approaching various classroom challenges and opportunities".

Another respondent stated,

"The fact that the mentoring program is there to help me is a comforting thought. It gives me an instant sense of relief to know that someone is there to help. A variety of topics in workshops is the best thing done by mentoring program organizers".

Another respondent said,

"I like that the program offered different kinds of workshops that helped us to reflect on our teaching practices. I appreciate the fact that the whole mentorship team was cooperative and working as a unit, not as an individual, which increased our productivity".

\section{What do you think we should change or do differently in the next academic year?}

To control or minimize problems and challenges facing mentors and mentees during mentoring, the respondents of this study were asked to suggest some ways and strategies. Some beneficial and practical suggestions were put forward. Here some prominent of them are summarized:

One of the respondents suggested in this statement,

"I believe the mentoring program has a great opportunity to assist new teachers before they even arrive in Saudi. I would have loved to be paired with a mentor perhaps one month before I arrived so I could get a better idea of the culture of the institution, expectations, and I would have a trusted resource with whom I could ask questions and a friendly face who could then help orient me to campus once I arrive. Of course, clear expectations of the mentor-mentee roles would have to be clarified so the mentor is not overwhelmed with questions that should be directed at other departments of the ELI (recruitment, HR, etc.) but I think it would assist greatly with the onboarding process for new hires".

Another respondent stated,

"If the same mentor/mentee relationships continue in the academic year, maybe each pair could work on a mini-presentation to present together, that way the mentees have the opportunity to get presentation experience in a very friendly forum".

Respondent 3 suggested,

"Provide a different kind of workshop such as workshops or presentations in the domain of research. Moreover, it would be beneficial to conduct workshops on how to use different programs for research such as, Nvivio, Endnote, etc."

\section{How has your overall experience with the Mentoring Program been so far?}

To improve strategies and plans of the mentoring program, question was asked to mentors and mentees. One of the respondents highlighted,

"Being a part of the Mentoring Committee has been an enriching experience for me. This opportunity has enabled me to share my knowledge and expertise in the field of teaching. It has renewed my enthusiasm for coaching and 
counseling. This opening has also enhanced my listening skill and interactive ability. Above all, it provided me with a platform to give my first presentation at ELI which I consider as my stepping stone towards my professional development".

Another respondent shared her experience,

"Well, I would like to begin with a big thanks to this Mentoring Committee to provide us such a platform where we can share our expertise, develop our professionalism, polish our skills as an English language instructor and as a mentor too in the form of presentations, workshops and meetings".

Respondent 3 stated,

"Mentoring program is considered a great and powerful development tool for both mentors and mentees and the ELI. It keeps the teachers happy, motivated and engaged at work. It has been a rewarding experience knowing that I have been able to help another colleague professionally, and in the process, I have learnt a lot too".

Another respondent stated,

"The skills I possess in this role include, 1. Encouraging (by helping mentees link their goals and objectives to become more involve in their work) 2. Providing Corrective Feedback (suggesting alternatives ways to conduct classroom management; to engage students in learning, etc.) 3. Managing Risks (includes patience, inspire commitment, cultural sensitivity, and maintaining appropriate attitude)".

During this mentoring experience what skills, knowledge and/or personal attributes did you use in your role as a mentor? Please be as specific as possible.

In the response of this question, many of participant mentors recorded their responses. One of the mentor respondents stated,

"To be hones, seems a hidden talent has emerged out of me as soon as I got this honor of being a mentor. The spirit and skill of coordination, mutual understanding and cooperation popped out somewhere. It's a wonderful experience by utilizing my passion for being "the best person to approach in case of any problem or need".

Another mentor participant said,

"My strong communication skills, practical approach and realistic solutions to challenges faced by us in English classes and my long career of dealing with ELI students all these helped me become a good mentor".

Another mentor respondent highlighted,

"I used my knowledge of teaching techniques I had used in my classes to explain to my mentee, as well as sharing with her knowledge of what obstacles we could encounter in our classes \& how to overcome them in the best possible way".

Respondent 4 shared her experience,

"I shared with my mentee the necessity \& importance of being patient, understanding, treating students with respect and being diligent where teaching in the class is concerned".

"Skills involving teaching reading, writing and listening in the best possible way, using different techniques with varied ability learners. Sorting out problems and discussing them with peers for possible solutions is really interesting and very useful".

Another respondent shared her experience,

"I have used the knowledge acquired over the years in teaching skills \& in solving problems that may occur on a day to day level in the class. My colleagues and I shared experiences of our educational life and the obstacles we had during our teaching and learning”.

\section{What would you suggest to improve the mentoring program?}

The most important question of this study is asking about the suggestions to improve the mentoring program. When the participants were asked, one of them suggested that,

"On the other hand, conducting workshops/presentations every two weeks to address topics of interest to the mentees after analyzing their answers to training needs questionnaire, which was conducted at the beginning of this academic year, was supposed to be very motivating for mentees to attend and actively participate in the discussions. However, many mentees' reluctance to show up and actively participate in the activity might ring a bell that it might be helpful to try other mentoring activities as well, which were successful in the previous years, such as organizing demo sessions for mentees to observe excellent ELI teachers in action, write reflections on their 
performance and then discuss these reflections with their mentors and/or class teachers to consolidate the one-on-one mentoring experience and fulfil the desired mentoring goals".

Another participant responded,

"In my opinion, mentoring is all about mentees and mainly designed to support them in order to enhance their teaching practice. Face- to -face mentoring is the best practice so far. However, due to some mentees' reluctant attitude to cooperate with their mentors, it'd be difficult to generalize its success. I suggest that offering face-to-face mentoring to be optional and to be offered upon mentees' request to avoid negative attitude".

Another respondent suggested,

"Workshops and presentations are designed to meet mentees' needs and based on their interests to enhance their teaching skills. Obviously, mentees are not interested in enhancing their skills and benefit from these valuable sessions. I recommend sending invitations to mentees to sign up for these sessions if they are interested. If not, the session should be cancelled. Generally, the success of any program action plan and activities should be measured and should allow for changes and improvement".

Respondent 4 praised and suggested,

"Well, it's already a 7-star program but as a suggestion I would like to add just that when there is a workshop or presentation, please make sure that we all don't have any other sort of mandatory meeting or presentation to attend at ELI. For example, when there were CEA visit preparation workshops by PDU, last month; I missed some of the very fruitful presentations by one of our dear mentors and I think many others also missed that. Alternatively, if in case the clash is inevitable, at least we could have a chance to re-arrange that. That's all. Thank you".

\section{Discussion}

\subsection{One-on-One Mentoring Sessions}

One-on-one mentoring sessions are a vital part of any mentoring programs. This research study reveals that formal mentoring program has caused a positive impact on the professional development of both the mentors and the mentees. During mentoring sessions, mentees learnt new strategies and methods from their mentors. They familiarized themselves with classroom management. The principle objective of the mentoring program is to provide professional and committed teacher in every classroom. This study proves that mentors have developed such skills by holding one-to-one mentoring sessions with their mentees. Their mentees have improved their professional skills by attending mentoring meetings, PD workshops and training sessions. Most of the sessions were about lesson planning, classroom management, teaching methodologies and techniques, use of visual aids and differentiated instruction. Mentors shared their expertise with their mentees.

\subsection{The Impact on Overall Mentoring Program}

According to Mentors' point of view, the Mentoring Program has been an enriching experience for the mentees and enabled them to share the knowledge and expertise in the field of teaching. It has renewed their enthusiasm in coaching and counselling and also enhanced their listening skills and interactive abilities. It provided them with a platform to give the first presentation at ELI, where they could share their expertise, develop professionalism, and brush up their skills as an English language instructor and as a mentor too in the form of presentations, workshops, group discussions and focus group meetings. In the Mentees' point of view, the activities through dialogue as well as online search and information sharing were useful and beneficial. The mentees learned the Skills - how to structure lessons, strategies to engage students, ways of using WhatsApp to motivate students with videos, encouraging messages, and out-of-class activities, along with goal setting for better class management, resources and dealing with students and how to communicate with them.

The formal mentoring program has received considerable attention that is evident in the proliferation of academic and popular literature and research on the subject (Evans, Bourassa, \&Woolbright, 1985; Obleton, 1984). This study of a formal mentoring program implemented at a Higher Education Organization - English Language Institute of King Abdulaziz University - was conducted to determine the experiences of participating faculty members. In particular the study sought to identify the nature of the work issues discussed and the value perceived by participants as flowing from their involvement in a programmed mentoring relationship. The results revealed that providing professional development to teachers on mentoring could help to build capacity in two ways: quality mentoring of novice teachers through explicit mentoring practices and reflecting and deconstructing teaching practices for mentors' pedagogical advancements. This study highlights the potential of formal mentoring programs as a valuable and appropriate professional development strategy in higher education organizations. 


\section{Conclusion}

The formal mentoring program has been successfully implemented at the ELI in the WMC only of KAU. The findings presented in this article suggest that it might be valuable to implement the same program in all the University campuses. It will help to explore the effectiveness of formal mentoring program more precisely. Mentoring of novice teachers is the main objective of a formal mentoring program but it is not possible if the mentee is not willing to share his or her needs. English Language Institute believes in the continuous professional development of the faculty members. For this purpose, the ELI has set up an observation committee which observes formal classroom observation of the faculty members. Then, observers hold a meeting with the teacher and discuss weak and strong areas of the teacher. It is suggested that the observation committee should refer such teachers to the mentoring committee who have more developmental needs in their formal observations so that mentoring can work on their weak areas. By this way, we can improve the teaching skills of both novice and experienced teachers. The reward is a powerful motivator; therefore, it is recommended to conduct a ceremony to celebrate success and hard work of mentors and mentees at the end of the tenure of every mentoring program. It will not only make them feel appreciated but will also encourage the participation of other faculty members in the future. Mentoring Committee is working under Quality and Development Unit of the ELI. The findings proposed that there should be a separate unit instead of the committee to run a formal mentoring program for novice and in-service teachers more skillfully, precisely and efficiently.

It is clear from the synthesis of the research evidence presented here that formal mentoring of novice and in-service teachers' mentoring has much potential to produce a range of benefits for mentees, mentors and the institution. The benefits of mentoring programs are substantial for novice and veteran teachers. A formal mentoring program has demonstrated highly promising success analyzed by mentors and mentees' feedback on the mentoring program. Such productive mentoring programs hold a vital significance in training, developing and sustaining the faculty members both novice and experienced. Hence, it is strongly recommended that all universities must make endeavours to establish and implement a stable, candid and supportive mentoring program to share teaching practices, training skills and learning experiences with one another.

The evaluation process has identified some areas for improvement of the program which includes the need to expand mentor training, encourage novice and in-service mentees to take a more significant lead in the mentoring activities. Overall, the outcomes suggest that this mentorship program has served as an essential component of the ELI faculty's professional development program. Formal Mentoring program can help the mentees or novice teachers, in-service teachers and mentors in finding solutions to the challenges, which they face particularly in the EFL classes.Mentoring program is also helpful in dealing with the cultural differences, logistic issues, unfamiliar structural and organizational arrangements, different understanding of assessment, communication gaps and problems with the teacher and student relations. It supports both the mentors' and mentees' professional development and increases their motivation as stated in Hobson, et. al., (2009). Nevertheless, mentoring helps the mentees improve their teaching, which results in an increased feeling of security. Based on this conclusion, this study implies that formal mentoring is a beneficial part of the teacher development program.

\section{Acknowledgement}

The authors would like to thank all mentors and mentees of the ELI who participated in this formal mentoring program and voluntarily provided input until the completion of the study.

\section{References}

Abell, S. K., Dillon, D. R., Hopkins, C. J., McInerney, W. D. \& O’Brien, D. G. (1995). 'Somebody to count on'” mentor/intern relationships in a beginning teacher internship program. Teaching and Teacher Education, 11(2), 173-188. https://doi.org/10.1016/0742-051X(94)00025-2

Adey, K. (1997). First impressions do count: mentoring student teachers. Teacher Development, 1(1), 123-133.

Association for Supervision and Curriculum Development. (1999). Mentoring to improve schools. Alexandria, VA: ASCD.

Beck, C. \& Kosnick, C. (2000). Associate teachers in pre-service education: clarifying and enhancing their role. Journal of Education for Teaching, 26(3), 207-224. https://doi.org/10.1080/713676888

Bjerkholt, E. (2013). Opening closed rooms: A qualitative study on the content and dialogues in mentoring newly qualified teacher)", unipubpubl, PhD Monography, No 168, University of Oslo, Oslo. 
Bodoczky, C. \& Malderez, A. (1997). The INSET Impact of a Mentoring Course. In D. Hayes (Ed.). In-Service Teacher Development: International Perspectives. Hemel Hempstead: Prentice Hall. https://doi.org/10.1016/j.tate.2008.09.001

Bullough, R. V., Jr. (2005). Being and becoming a mentor: school-based teacher educators and teacher educator identity. Teaching and Teacher Education, 21, 143-155. https://doi.org/ 10.1016/j.tate.2004.12.002

Bullough, R. V., Jr. \& Draper, R. J. (2004). Mentoring and the emotions. Journal of Education for Teaching. International Research and Pedagogy, 30(3), 271-288. https://doi.org/10.1080/0260747042000309493

Carter, M. \& Francis, R. (2001). Mentoring and Beginning Teachers' Workplace Learning. Asia-Pacific Journal of Teacher education, 29(3), 249-262. https://doi.org/ 10.1080/13598660120091856

Crasborn, F., Hennisson, P., Brouwer, N., Korthagen, F. \& Bergen, T. (2008). Promoting versatility in mentor teachers' use of supervisory skills. Teaching and Teacher Education, 24, 499-514.

Clarke, A., Triggs, V. \& Nielsen, W. (2013). Cooperating teacher participation in teacher education: a review of literature. Review of Educational Research, 84(2), 163-202. https://doi.org/10.3102/0034654313499618

D. Cutler (2014). Why New Teachers Need Mentors, https://www.edutopia.org/blog/why-new-teachersneed-mentors-david-cutler (Edutopia, George Lucas Educational Foundation)

Danielson, C. (1999). Mentoring beginning teachers: The case for mentoring. Teaching and Change, 6(3), 251-257.

Davies, M. A., Brady, M., Rodger, E. \& Wall, P. (1999). Mentors and school-based partnership: ingredients for professional growth. Action in Teacher Education, 21(1), 85-96. https://doi.org/10.1080/01626620.1999.10462949

Delaney, Y. A. (2012). Research on Mentoring Language Teachers: Its Role in Language Education. Foreign Language Annals, 45(S1), S184-S202. (C) 2012 by American Council on the Teaching of Foreign Languages. https://doi.org/10.111/j.1944-9720.2012.01185.x

Denzin, N. (1988). The research act (Rev. ed.): New York: McGraw-Hill, p. 110.

Edwards, A. (1998). Mentoring student teachers in primary schools: assisting student teachers to become learners. European Journal of Teacher Education, 21(1), 47-62. https://doi.org/10.1080/0261976980210106

Dunne, E. \& Bennett, N. (1997). Mentoring processes in school-based training. British Educational Research Journal, 23, 225-238. https://doi.org/10.1080/0141192970230208

Ehrich, L. \& Hansford, B. (1999). Mentoring: pros and cons for HRM. Asia Pacific Journal of Human Resources, 37(3), 92-107. https://doi.org/10.1177/103841119903700307

Evans, L. \& Abbott, I. (1997). Developing as mentors in school-based teacher training. Teacher Development, 1(1), 135-148. https://doi.org/10.1080/13664539700200010

Evans, N.J., Bourassa, D. M. \& Woolbright, C. (1985). Working with young undergraduate women. In N. J. Evans (Ed.), Facilitating the development of women. New directions for student services: No. 29 (pp. 45-59). San Francisco: Jossey-Bass.

Evertson, C. \& Smithey, M. (2000). Mentoring effects on prote'ge' s' classroom practice: an experimental field study. Journal of Educational Research, 93(5), 294-304. https://doi.org/10.1080/00220670009598721

Feiman Nemser, S., McDiarmid G. W., Melnick, S. L. \& Parker, M. (1989). Changing beginning teachers' conceptions: a description of an introductory teacher education course (research report no. 89-1). Michigan State University, East Lansing, MI: The National Center for Research on Teacher Education. Available at $<$ http://ncrtl.msu.edu/http/rreports/html/pdf/rr891.pdf $>$ Accessed 15.04 .08

Feiman Nemser, S. \& Parker, M. B. (1992). Mentoring in context: A comparison of two U.S. programs for beginning teachers. Michigan, MI: Michigan State University, National Centre for Research on Teacher Learning (NCRTL). Available at. <http://ncrtl.msu.edu/http/sreports/spring92.pdf $>$. Accessed 15.04.08.

Foster, R. (1999). School-based initial teacher training in England and France: trainee teachers' perspectives compared. Mentoring and Tutoring: Partnership in Learning, 7(2), 131-143. https://doi.org/10.1080/1361126990070204

Franke, A. \& Dahlgren, L. O. (1996). Conceptions of mentoring: an empirical study of conceptions of mentoring during the school-based teacher education. Teaching and Teacher Education, 12(6), 627-641. https://doi.org/10.1016/S0742-051X(96)00004-2 
Gaede, O. F. (1978). Reality shock: a problem among first year teachers. The Clearing House, 51(8), 405-409. https://doi.org/10.1080/00098655.1978.9957085

Gay, B. \& Stephenson, J. (1998). The mentoring dilemma: guidance and/or direction? Mentoring and Tutoring: Partnership in Learning, 6(1), 43-54. https://doi.org/10.1080/0968465980060104

Gillham, B. (2005). Research interviewing: The range of techniques. Open University Press.

Goodlad, J. (1990). Teachers for our nation's schools. San Francisco, CA: Jossey-Bass. https://doi.org/10.1177/027046769201200274

GRIFFIN, G. A. (1983). Introduction: the work of staff development, in: G. A. GRIFFIN(Ed.) Staff Development, Eighty-Second Yearbook of the National Society for the Study of Education (Chicago, IL, University of Chicago Press).

Hagger, H. \& McIntyre, D. (2006). Learning teaching from teachers: Realising the potential of school-based teacher education. Maidenhead: Open University Press.

Harrison, J., Dymoke, S. \& Pell, T. (2006). Mentoring beginning teachers in secondary schools: an analysis of practice. Teaching and Teacher Education, 22, 1055-1067. https://doi.org/ 10.1016/j.tate.2006.04.021

Hascher, T., Cocard, Y. \& Moser, P. (2004). Forget about theory - practice is all? Student teachers' learning in practicum. Teachers and Teaching: Theory and Practice, 10(6), 623-637. https://doi.org/ $10.1080 / 1354060042000304800$

Hobson, A. J., Malderez, A., Tracey, L., Giannakaki, M. S., Pell, R. G. \& Tomlinson, P. D. (2008). Student teachers' experiences of initial teacher preparation in England: core themes and variation. Research Papers in Education, 23(4), 407-433. https://doi.org/10.1080/02671520701809825

Hobson, A. J., Ashby, P., Malderez, A. \& Tomlinson, P.D. (2009). Mentoring beginning teachers: what we know and what we don't. Teaching and Teacher Education, 25(1), 207-216.

Heilbronn, R., Jones, C., Bubb, S. \& Totterdell, M. (2002). School-based induction tutors - a challenging role. School Leadership and Management, 22(4), 371-388. https://doi.org/ 10.1080/1363243022000053402

Ingersoll, R. \& Kralik, J. (2004). The impact of mentoring on teacher retention: What the research says. Denver, CO: Education Commission of the States. Available at. < http://www.ecs.org/clearinghouse/50/36/5036. $\mathrm{htm}>$. Accessed 15.04.08.

Johnson, S., Berg, J. \& Donaldson, M. (2005). Who stays in teaching and why; a review of the literature on teacher retention. The Project on the Next Generation of Teachers: Harvard Graduate School of Education.

Korthagen, F. A. J., Kessels, J., Koster, B., Lagerwerf, B. \& Wubbels, T. (2001). Linking practice and theory: The pedagogy of realistic teacher education. Mahwah, NJ: Lawrence Erlbaum Associates.

Larose, S., Savoie, J., DeWit, D.J., Lipman, E.L. \& DuBois, D.L. (2015). The role ofrelational, recreational, and tutoring activities in the perceptions of received supportand quality of mentoring relationship during a community-based mentoringrelationship. Journal of Community Psychology, 43(5), 527-544. https://doi.org/10.1002/jcop. 21700

Lee, J. C. \& Feng, S. (2007). Mentoring support and the professional development of beginning teachers: a Chinese perspective. Mentoring and Tutoring: Partnership in Learning, 15(3), 243-263. https://doi.org/ $10.1080 / 13611260701201760$

Lindgren, U. (2005). Experiences of beginning teachers in a school-based mentoring programme Sweden. Educational Studies, 31(3), 251-263. https://doi.org/ 10.1080/03055690500236290

Little, J. W. (1990). The mentor phenomenon and the social organization of teaching. In C. B. Cazden (Ed.), Review of research in education, Vol. 16 (pp. 297-351). Washington, DC: American Educational Research Association.

Lopez-Real, F. \& Kwan, T. (2005). Mentors' perceptions of their own professional development during mentoring. Journal of Education for Teaching, 31(1), 15-24. https://doi.org/ 10.1080/02607470500043532

Malderez, A., Hobson, A. J., Tracey, L. \& Kerr, K. (2007). Becoming a student teacher: core features of the experience. European Journal of Teacher Education, 30(3), 225-248. https://doi.org/10.1080/02619760701486068 
Marable, M. \& Raimondi, S. (2007). Teachers' perceptions of what was most (and least) supportive during their first year of teaching. Mentoring and Tutoring: Partnership in Learning, 15(1), 25-37. https://doi.org/10.1080/13611260601037355

Martin, M. \& Rippon, J. (2003). Teacher induction: personal intelligence and the mentoring relationship. Journal of In-Service Education, 29(1), 141-162. https://doi.org/ 10.1080/13674580300200204

Martin, S.M. \& Sifers, S.K. (2012). An evaluation of factors leading to mentor satisfactionwith the mentoring relationship. Children and Youth Services Review, 34(5), 940-945. https://doi.org/10.1016/j.childyouth.2012.01.025

Maynard, T. (2000). Learning to teach or learning to manage mentors? Experiences of school-based teacher training. Mentoring and Tutoring: Partnership in Learning, 8(1), 17-30. https://doi.org/10.1080/713685510

McIntyre, D. \& Hagger, H. (1996). Mentors in schools: Developing the profession of teaching. London: David Fulton.

Moor, H., Halsey, K., Jones, M., Martin, K., Stott, A., Brown, C. \& Harland, J. (2005). Professional development for teachers early in their careers: An evaluation of the early professional development pilot scheme. Nottingham: Department for Education and Skills.

Murray, M. \& Owen, M. A. (1991). Beyond the myths and magic of mentoring: How to facilitate an effective mentoring programme. San Francisco, CA: Jossey Bass.

National Association of State Boards of Education. (1998). The numbers game. Alexandria, VA: Author.

Ohata, K. (2005). Language anxiety from the teachers' perspective: Interviews with seven experienced ESL/EFL teachers. Journal of Language and Learning, 3(1), 133-155.

Parlo, S. \& Allen, J \& Rowan, L. (2017). Teacher education programs: local and global connections. Asia-Pacific Journal of Teacher Education, 45(1), 1-2, https://doi.org/ 10.1080/1359866X.2017.1265762.

Patton, M. Q. (1990). Qualitative evaluation methods: Thousand Oaks. Sage. https://doi.org/10.1002/nur.4770140111

Price, M. L. (1991). The subjective experience of foreign language anxiety: Interviews with highly anxious students. Language Anxiety. From Theory and Research to Classroom Implications. Upper Saddle River, NJ. Prentice Hall, 101-108.

Rajuan, M., Douwe, B. \&Verloop, N. (2007). The role of the cooperating teacher: bridging the gap between the expectations of cooperating teachers and student teachers. Mentoring and Tutoring: Partnership in Learning, 15(3), 223-242. https://doi.org/ 10.1080/13611260701201703

Rao, V. (2019). The Significance of Mentoring Programs in English Language Teaching. Journal for Research Scholars and Professionals of English Language Teaching, 11(3).

Rikard, G. L. \& Banville, D. (2010). Effective Mentoring: Critical to the Professional Development of First Year Physical Educators. Journal of Teaching in Physical Education, 29(3), 245-261

Roberts, A. (2000). Mentoring revisited: a phenomenological reading of the literature. Mentoring and Tutoring, 8(2), 145-166. https://doi.org/ 10.1080/713685524

Robinson, I. \& Robinson, J. (1999). Learning to live with inconsistency in student entitlement and partnership provision. Mentoring and Tutoring: Partnership in Learning, 7, 223-239. https://doi.org/ 10.1080/1361126990070304

Robson, C. (2000). Small-scale evaluation: Principles and practice. Sage Publications Ltd.

Roehrig, A. D., Bohn, C. M., Turner, J. E. \& Pressley, M. (2008). Mentoring beginning primary teachers for exemplary teaching practices. Teaching and Teacher Education, 24, 684-702. https://doi.org/ 10.1016/j.tate.2007.02.008

Schmidt, M. (2008). Mentoring and being mentored: the story of a novice music teacher's success. Teaching and Teacher Education, 24, 635-648. https://doi.org/ 10.1016/j.tate.2006.11.015.

Simpson, T., Hastings, W. \& Hill, B. (2007). I knew that she was watching me: the professional benefits of mentoring. Teachers and Teaching: Theory and Practice, 13(5), 481-498. https://doi.org/10.1080/13540600701561695 
Smith, T. \& Ingersoll, R. (2004). What are the effects of induction and mentoring on beginning teacher turnover? American Educational Research Journal, 41(3), 681-714.

Stanulis, R. N. \& Weaver, D. (1998). Teacher as mentor, teacher as learner. The Teacher Educator, 34(2), $134-143$

Storms, B., Wing, J., Jinks, T., Banks, K. \& Cavazos, P. (2000). CFASST (field review) implementation 1999-2000: A formative evaluation report. Princeton, NJ: Educational Testing Service.

Sugrue, C. (1996). Student teachers' lay theories: Implications for professional development. In I. F. Goodson \& A. Hargreaves (Eds.), Teachers' professional lives (pp. 154-177). Washington, DC: Falmer Press.

Tauer, S. M. (1998). The mentor-prote'ge' relationship and its impact on the experienced teacher. Teaching and Teacher Education, 14(2), 205-218.

The National Education Association (2005). A Manual for ESP Mentoring Program, Washington, DC. Tips for Establishing a Successful mentoring Program: https://learningsolutionsmag.com/articles/tips-for-establishing-a-successfulmentoring-program.

ValencicZuljan, M. \& Vogrinc, J. (2007). A mentor's aid in developing the competences of teacher trainees. Educational Studies, 33(4), 373-384. https://doi.org/ 10.1080/03055690701423473

Van Dam, L., Smit, D., Wildschut, B., Branje, S.J.T., Rhodes, J.E., Assink, M. \& Stams, G.J.J.M. (2018). Does natural mentoring matter? A multilevel meta-analysis on the association between natural mentoring and youth outcomes. American Journal of Community Psychology, 62, 203-220. https://doi.org/ 10.1002/ajcp.12248.

Veenman, S., Denessen, E., Gerrits, J. \& Kenter, J. (2001). Evaluation of a coaching programme for cooperating teachers. Educational Studies, 3, 317-340. https://doi.org/ 10.1080/03055690120076592

Wang, J. \& Odell, S. J. (2002). Mentored learning to teach according to standards based reform: a critical review. Review of Educational Research, 72(3), 481-546. https://doi.org/ 10.3102/00346543072003481

Wang, J. \& Odell, S.J. (2007). An alternative conception of mentor-novice relationships: learning to teach in reform-minded ways as a context. Teaching \& Teacher Education, 23(4), 473-489. https://doi.org/10.1016/j.tate.2006.12.010.

Wildman, T. M., Magliaro, S. G., Niles, R. A. \& Niles, J. A. (1992). Teacher mentoring: an analysis of roles, activities, and conditions. Journal of Teacher Education, 43, 205-213. https://doi.org/ $10.1177 / 0022487192043003007$

Wright, N. \& Bottery, M. (1997). Perceptions of professionalism by the mentors of student teachers. Journal of Education for Teaching, 23(3), 235-252.

World Federation of Nuclear Medicine and Biology (WFNMB) https://www.wfnmb.org/cpd

Wubbels, T. (1992). Taking account of student teachers' preconceptions. Teaching and Teacher Education, 8(2), 137-149. https://doi.org/ 10.1016/0742-051X(92)90004-M

Yeomans, R. \& Sampson, J. (1994). Mentorship in the primary school. London: Falmer Press.

Yusko, B. \& FeimanNemser, S. (2008). Embracing contraries: combining assistance and assessment in newteacher induction. Teachers College Record, 110(7), 1-12. ERIC Number: EJ825504.

Zhou, A.J., Lapointe, É. \& Zhou, S.S. (2018). Understanding mentoring relationships in China: Towards a Confucian model. Asia Pacific Journal of Management, 8, 1-30. https://doi.org/ 10.1007/s10490-018-9589-5.

\section{Copyrights}

Copyright for this article is retained by the author(s), with first publication rights granted to the journal.

This is an open-access article distributed under the terms and conditions of the Creative Commons Attribution license (http://creativecommons.org/licenses/by/4.0/). 